\title{
Fuat Sezgin’in Bedî‘ ilminin Doğuşu ile İlgili Görüşleri (Bedî‘ illmi ile Ilgili Bitirme Tezi Bağlamında)
}

\author{
Fatma Nur Şener ${ }^{1}$ [C]
}

Öz

İslam medeniyetinin kitâbiyat üzerine önemli çalışmalar kaleme alan Fuat Sezgin, İstanbul Üniversitesi Şarkiyat Araştırmaları Enstitüsü’ndeki eğitimini 1947 yılında Arap ve İran Filolojisi bölümünde hazırladığı "Bedî‘ ilıminin Tekamülü ve İstanbul Kütüphanelerinde Bulunan Bedîiyyelere Ait Yazmalar Kataloğu" başlıklı tezi ile tamamlamıştır. Sezgin, teze başlarken bedîiyye türünü incelemeyi ve İstanbul yazma eser kütüphanelerinde yer alan bedîyyâtın kataloğunu çıkarmayı amaçlamıştır ancak çalışması esnasında izah etmeyi zaruret addettiği; beyân ilminin Câhiz'la (ö. 255/869) başlatılması, İbnü'l-Mu'tez'in (ö. 296/908) zikrettiği bedî‘ nevilerinde ani bir artışın bulunması, Kudâme b. Ca'fer'in (ö. 337/948) Nakdü'ş-şi'r'inde kendisini bu alanda eser telif edenlerin ilki olarak zikretmesi gibi bir takım meselelerle karşılaşmıştır. Bu meselelerden yola çıkarak özelde bedî‘ ilminin genel olarak ise belâgatın doğuşu ve gelişimi hakkında hâlihazırda da canlılı̆ını sürdüren tartş̧malara dâhil olmuştur. İbnü'l-Mu'tez'in Kitabu'l-bedî́i ile bir disiplin olarak ortaya çıktı̆̆ kabul edilen bedî‘ ilminin menşeinde Yunan felsefesinin tesirinin olduğu hususunda modern dönemde tartşmalar cereyan etmiştir. Kitâbu'l-bedînin telif edilme sürecinden yola çıkarak yaptığı tetkiklerle bedî’ ilminin tarihini iki safhaya ayıran Fuat Sezgin, İbnü'l-Mu'tez'in kitabının bölümleri arasında bir ayrıma gitmiş ve kitabın ikinci bölümünü Aristo'nun Rhetorica'sından (Kitâbü'l-Hatâbe) istifade ederek telif ettiği kanaatine varmıştır. Bu kanaatini İbnü'l-Mu'tez'in çağdaşı olan Kudâme b. Ca'fer'in Nakdü'ş-şi'r'inde de Aristo etkisinin açıkça tespit edilebilir olmasıyla desteklemiştir. Bu çalışmada ise Fuat Sezgin'in bedî' sanatlarının tarihçesine yönelik söz konusu tespitlerini ve argümantasyonunu analiz edilmeye çalışılacaktır.

\section{Anahtar Kelimeler \\ Rhetorica, belâgat, beyan, bedî', İbnü'l-Mu'tez}

\section{Fuat Sezgin's Views on the Origins of IIm al-Badi (In the context of his Dissertation on IIm al-Badi)}

\begin{abstract}
Fuat Sezgin, who wrote important studies on Islamic literature, completed his education at the Istanbul University Institute of Oriental Studies with his dissertation titled "Bedî‘ IIIminin Tekamülü ve İstanbul Kütüphanelerinde Bulunan Bediiyyelere Ait Yazmalar Kataloğu" in 1947. Sezgin aimed to examine the genre of badîyyah and to produce a catalog of badîiyyât in Istanbul manuscript libraries. Moreover, he considers it necessary to explain in his work the following: the beginning of rhetoric (al-balagha) with Jahiz (d. 255/869), the sudden increase in rhetorical forms used by Ibn al-Mu'tazz (d. 296/908), and Qudâma b. Ja'fer's (d. 337/948) acceptance of himself in this field as the first author. Based on these issues, he has already been involved in debates regarding the origins and development of rhetoric. In the modern period, there has been a debate on the influence of Greek philosophy on the origins of rhetoric, which is accepted as a discipline with the book of Ibn al-Mu'tazz called Kitab al-Badi. Fuat Sezgin, who divides the history of al-badi into two phases with the examinations he made based on the writing process of Kitab al-Badi, made a distinction between the chapters of Ibn al-Mu'tazz. Sezgin concluded that İbn al-Mu'tazz was influenced by Aristotle in the second part of the book. He supported
\end{abstract}

1 Sorumlu Yazar: Fatma Nur Şener (Arş. Gör.), İstanbul Üniversitesi, İlahiyat Fakültesi, Tefsir Anabilim Dalı, İstanbul, Türkiye.

E-posta: fnsener@istanbul.edu.tr ORCID: 0000-0003-3709-1092

Atıf: Sener, Fatma Nur. "Fuat Sezgin'in Bedî‘ IIIminin Doğuşu ile İlgili Görüşleri (Bedî‘ ilımi ile İlgili Bitirme Tezi Bağlamında)." darulfunun ilahiyat, 30, 'Fuat Sezgin' Özel Sayısı (2019): 67-91. https://doi.org/10.26650/di.2019.30.2.0051 
this conviction with the detectable Aristotle effect in Qudâma, a contemporary of Ibn al-Mu'tazz. In this study, Fuat Sezgin's findings and argumentation about the history of the rhetorical arts will be analyzed.

\section{Keywords}

Rhetorica, balagha, bayan, badî ', İbn al-Mu'tazz

\section{Extended Summary}

Fuat Sezgin graduated from the Oriental Studies Institute of Istanbul University with a thesis entitled "Evolution of Ilm al-Badi and Catalog of Badí'iyya Manuscripts in Istanbul Libraries". His first aim was to identify the badí 'iyya manuscripts in the libraries of Istanbul, but he later faced some problems with the history of ilm al-badi. Therefore he set himself to researching the history of rhetoric (ilm al-balagha). His thesis has not been discussed in any academic study before and his views have not been revealed. It is thought that these views will contribute to the writing of history because they contains original claims. This study aims to evaluate the information included in the thesis and to draw attention to its importance.

Ilm al-badi, which is one of the three sciences that compose ilm al-balagha, examines the ways of embellishing expressions. Badī'iyya is a special kind of poetry written to praise the prophet, Muhammad. Certain conditions are sought in badī iyya poems: there must be at least one rhetorical form in each couplet, the number of couplets should be at least 50, etc. The first poet of this genre was Șafī al-Dīn al-Hilli (died 1348). About 100 poems in this genre were written by the 20th century after al- al-Hilli. Fuat Sezgin, in his thesis study, provided information on 17 badī iyya poems, their poets and the badī iyya manuscripts in Istanbul libraries.

The first issue regarding the history of al-balagha that Fuat Sezgin reviewed is Aristotle's effect on the rise of al-badi. Before him, Taha Hussein was the first to draw attention to this effect. However, he could not examine the Kitab al-Badi by Abdallah Ibn al-Mu'tazz. In his paper presented at the conference of orientalists in Leiden in 1931, Hussein stated that al-balagha was influenced by Aristotle. At that time, Kitab alBadi had not yet been published - Ignatij Julianovič Kračkovskıj published it in 1935 (London). Fuat Sezgin examined Kitab al-Badi and tried to determine the effect he was highlighting. Sezgin established a relationship between the chapters of the book and the developmental stages of al-badi. He thinks that the topics discussed in the first part of the book are already known, however, the second part of the book was written per the influence of Aristotle.

One of the problems related to the history of al-balagha to which Sezgin had tried to propose a solution is Qudâma b. Ja'fer's claim in his book Nakd al-Shi'r that he was the first author in the field of rhetorical forms. Sezgin was convinced that Qudâma who was one of the dewan clerks in the Abbasid period, could not ignore that Ibn al-Mu'tazz had 
written a book about al-badi. Therefore Qudama must not have seen his book. However, it is unthinkable that Qudama did not see Kitab al-Badi since he was one of the leading intellectuals of his time. Consequently, Fuat Sezgin came to a conclusion that when Qudama started writing his book, Ibn al-Mu'tazz had not yet written the second part of Kitab al-Badi. In other words, they both wrote about rhetorical forms at the same time. That's why they both thought themselves to be the first person to approach ilm al-badi.

Another point that Fuat Sezgin deems problematic in terms of the history of al-balagha is the rise and development phase of rhetoric from its beginnings to Hijri III. century. Sezgin objected to the initiation of al-balagha and the three sciences contained in it by specific individuals. He asserted that the emergence of al-ma'ani, al- bayan and al-badi as a science is based on previous periods. The history of ilm al-bayan is initiated by the work of Jahîz Kitāb al-bayān wa al-tabyīn, however, Fuat Sezgin acknowledges that in this period, al-bayan meant al-balagha in a broad sense and that the study of Jahiz contributed to its development as a discipline.

Fuat Sezgin's approaches to the issues he dealt with in the origins and development of al-balagha have original explanations. Nevertheless, it is a deficiency in the historical writing of al-balagha that Fuat Sezgin's contributions were not included. 


\section{Giriş}

Fuat Sezgin, İstanbul Üniversitesi Şarkiyat Araştırmaları Enstitüsü’nde bitirme tezi olarak kaleme aldığı "Bedî‘ İlminin Tekamülü ve İstanbul Kütüphanelerinde Bulunan Bediiyyelere Ait Yazmalar Kataloğu" başlıklı tez çalışmasında bedîiyye türünü incelemeyi ve İstanbul kütüphanelerindeki bedîiyye türüne ait yazma eserlerin kataloğunu yapmayı amaçlamıştır. Bedîiyyeler üzerine yaptığı araştırması esnasında belâgat ilimlerinin doğuşu ve gelişimi ile ilgili incelemeler yapmış, bu doğrultuda bedî‘ ilminin ortaya çıkmasında Yunan felsefesinin tesiri olduğu yönünde bir tespitinde bulunmuştur. Yunan felsefesinin belâgatın doğuşuna tesir ettiği yönündeki tartışma geçtiğimiz yüzyılda ortaya çıkmış ve günümüzde de hararetini korumaya devam etmektedir. Taha Hüseyin (ö. 1966), Emîn el-Hûlî (ö. 1966), Berkūkī (ö. 1944), Hellmut Ritter (ö. 1971), Şevkî Dayf (ö. 2005), Fazl Hasan Abbas (ö.2011) gibi pek çok entelektüelin ve belâgat tarihi araştırmacılarının ele aldığı söz konusu etkileşim üzerine Fuat Sezgin'in mezkûr tezinde yer verdiği görüşlerinin daha önce araştırma konusu edilmediği görülmüştür Zira Fuat Sezgin'in mezkur tez çalışması daha önce araştırmacılar tarafindan bulunmamış olup ilk defa bu çalışmada konu edinilmektedir. Bedî‘ ilminin tarihçesi üzerine Fuat Sezgin'in katkılarını gündeme getirmenin, belâgat tarihi yazıcılığ 1 açısından bir eksikliğe dikkat çekmeye matuf bir çalışma olacağı düşünülmektedir.

Bitirme tezinde Fuat Sezgin'in bedî‘ başta olmak üzere belâgat ilimlerinin teşekkül tarihine dair mülahazalarından tespit ettiğimiz üç temel meseleyi; beyân ilminin Câhiz'la (ö. 255/869) başladığının kabul edilmesine rağmen daha önce beyana dair eserler kaleme alanların mevcudiyeti, İbnü'l-Mu'tez'in (ö. 296/908) Kitâbü 'l-Bedî ' eserinin döneminin çalışmalarından farklı bir türde olması, Kudâme b. Ca'fer'in (ö. 337/948) Nakdü'ş-Şi 'r' inde kendisinin bu alanda ilk eseri telif ettiğini zikretmesi ancak ondan önce İbnü'l-Mu'tez'in mezkur eserinin mevcut olması şeklinde kısaca ifade etmek mümkündür. Zikredilen meseleler çalışmamızın ana konusunu oluşturmakla beraber konunun değerlendirilmesinde faydalı olacağı düşünüldüğünden, araştırmanın birinci bölümünde bedi' ve bedîiyyat kavramlarına temas edildikten sonra kısaca belâgat tarihine ve modern dönemde ortaya çıkan tartışmalara değinilecek, akabinde Fuat Sezgin'in yaklaşımları ele alınacaktır.

Literatürde tespit edebildiğimiz kadarıyla İbnü'l-Mu'tez'in Kitâbü'l-Bed̂े ‘ eserinde Aristo etkisini inceleyen müstakil bir çalışma bulunmamaktadır. Bununla beraber Aristo'nun Arap belâgatına etkisi üzerine müstakil çalışmalar kaleme alınmıştır. Bu çalışmalar arasında Abbas Erhîle'nin el-Eserü'l-Aristiyyu fi' $n$-Nakd ve'l-Belâgati'l-Arabiyyîn adlı kapsamlı eseri örnek gösterilebilir. Mezkur kitapta Kitâbü'l-Bedî̀'de Aristo tesiri ile ilgili bir başlığa yer verilmiş olup, bu tartışma Taha Hüseyin'in iddiası üzerinden değerlendirilmiştir. Belâgatta Aristo etkisini 
ele alan bir diğer çalışma olan Fazl Hasan Abbas'ın el-Belâgatü 'l-Müfterâ Aleyhâ Beyne'l-Esâle ve't-Tebeiyye eserinde cevap verilen iddialar Taha Hüseyin'e ait olup, Fuat Sezgin'e değinilmemiştir. Ülkemizde belâgat tarihi araştırmacılarından Zafer Kızıklı ve Nusrettin Bolelli de çalışmalarında ${ }^{1}$ Fuat Sezgin'in bedî‘ ilmiyle ilgili değerlendirmelerini ele almamışlardır. Yine aynı şekilde Kudâme b. Ca'fer ve İbnü'l-Mu'tez'in kendi çalışmalarını alandaki ilk eser olarak yansıtmları üzerine tarihsel bir çözümleme getirilmemiştir. Dolayısıyla Fuat Sezgin'in özgün yaklaşımlar içeren değerlendirmelerini gündeme getirmek önem arz etmektedir.

\section{Kavramsal Çerçeve}

Belâgat tarihi bağlamında yer verilecek olan mülahazalarda sıç̧a kendilerine müracaat edilmesi hasebiyle meânî, beyân ve bedî‘ ıstılahlarını tanımlamak gerekli görülmektedir. Bununla beraber özel bir tür kaside anlamında kullanılan bedîiyye kavramı ile neyin kastedildiğini netleştirmenin yararlı olacağı düşünülmektedir.

\section{Belâgat: Meânî, Beyân ve Bedî̀}

Sözün fasih, açık ve seçik olması anlamına gelen belâgat, bir edebiyat terimi olarak meleke (eloquence).ve ilim (rhetorique) olmak üzere iki farklı kullanım alanına sahip olmuştur. ${ }^{2}$ Bir sözün beliğ olması için fasih olmakla beraber muktezây1 hâle (durumun gereğine) uygun olarak söylenmesi gerektiği kabul edilmektedir. ${ }^{3}$ Çalışmanın devamında tarihçesine yer verilecek olan belâgatın meânî, beyân ve bedî‘ ilimleriden müteşekkil bir ilim olduğu kabul edilmektedir. ${ }^{4}$ Dolayısıyla bedî ilminden bahsedebilmesi için meânî ve beyân ilimlerinin tanım ve kapsamlarına temas edilmesi faydalı olacaktır.

Meânî ilmi, sözü muktezâ-yı hâle mutabakatı açısından ele alan bir ilimdir. Ele aldığ 1 sekiz temel konu bulunmaktadır: haberî isnadın halleri, müsnedün ileyhin halleri, müsnedin halleri, fiile müteallıkların halleri, kasır, inşâ, fasıl-vası1, îcaz-itnab-müsâvat. ${ }^{5}$ Beyân ilmi ise bir manayı muhtelif şekillerde ifade etmenin yollarını araştıran bir ilimdir. Teşbih, istiâre, hakikat-mecaz, kinaye konularını ele

1 Zafer Kızıkl1, Arap Dilinde Belâgat Bilimi (Tarihsel ve Kavramsal Bir Çözümleme) (Ankara:2008); Nusrettin Bolelli, Belâgat Tarihi (İstanbul: Rağbet Yayınları, 2018).

2 Hulûsi Kılıç, "Belâgat," Türkiye Diyanet Vakfi İslam Ansiklopedisi (İstanbul: TDV Yayınları, 1992), 5: 380 .

3 Ebü'l-Meâlî Celâlüddîn el-Hatîb Muhammed b. Abdirrahmân el-Kazvînî, Telhîsü'l-Miftâh, thk. Abdurrahman el-Berkûkî (Dârü'l-Fikri'l-Arabî, 1932), 33.

4 Kılıç, "Belâgat," 381.

5 Kazvînî, Telhîs, 37-38. 
almaktadır. ${ }^{6}$ Meânî ve beyân ilimlerinin bir tamamlayıcısı olarak da kabul edilen bedî‘ ilmi tahsînü'l-kelâm maksadiyla kendisine müracaat edilen sanatlardan oluşmaktadır. Mukteza-yı hâle mutabık olan fasih sözü güzelleştirmenin yollarını ele alan bedî‘ ilminde ${ }^{7}$ söz sanatları lafzî ve manevî kısımlara ayrılmak suretiyle ele alınmaktadır. ${ }^{8}$ Bedî‘ ilminde ele alınan söz sanatları kimi zaman diğer disiplinlerin konuları ile tedahül halinde olmuştur. Söz gelimi Ebû Hilâl el-Askerî’nin bedî‘ ile ilgili eserinde zikrettiği 35 söz sanatının bir kısmı bugünkü anlamıyla beyân ilminin kapsamına girmektedir. ${ }^{9}$

Sayıları 126'ya kadar çıkartılabilen bedî‘ sanatlar1 ${ }^{10}$ üzerine teorik düzlemde yapılan ilk çalışmayı kaleme alan İbnü'l-Mu tez, kitabında 18 adet söz sanatı tespit etmiştir. İbnü’'l-Mu’ tez bedî‘ kavramını muhdesûn şiirindeki yenilikleri ifade eden sanatların her birini ifade etmek için kullanmıştır. Kendisinin bu kullanımının öncesinde muhdesûnun yeni ve benzersiz şiirini ifade etmek için kullanıllyordu. Câhiz bedî‘ kelimesini el-Beyân'da bir yerde zikretmiş olmakla beraber Araplardan başka hiçbir millette görülmeyen şiir manasında kullanmıştır. ${ }^{11}$ Bedî‘ kelimesinin terim olarak kullanılmasını öneren ilk kişinin Müslim b. el-Velîd el-Ensârî (ö. 208/823) olduğu nakledilmektedir. ${ }^{12}$

\section{Bedîiyyât}

Bedî‘ ilmi teorik gelişimini tamamlarken bir yandan da bedîiyye (çoğulu bedîiyyât) literatürü içerisinde pratik gelişimini ortaya koymuştur. ${ }^{13}$ Hicî VIII. asırdan itibaren telif edilmeye başlanan bedîiyyeler özel bir tür kaside olup, Hz. Muhammed'i methetmek üzere nazmedilen eserlerdir. ${ }^{14}$ Bir kasidenin bedîiyye

6 Kazvînî, , Telhîs, 236.

7 Ali Bulut, Bedî‘ İlmi (İstanbul: M.Ü. İlahiyat Fakültesi Yayınları, 2016), 36.

8 Ebu Yakub Siracüddin Yusuf es-Sekkâkî, Miftâhu'l-Ulûm, thk.Nuaym Zerzûr (Beyrut: Dârü'lKütübi'l-İlmiyye, 1407/1987), 423.

9 Zafer Kızıklı, "Arap Dilinde Retoriğin Bir Bilim Dalı Olarak Doğuşu, Gelişimi ve Öncüleri," ICANAS 38 Uluslararası Asya ve Kuzey Afrika Çalışmaları Kongresi (Ankara: 2007), 1022.

10 Nasrullah Hacımüftüoğlu, "Bedi,” Türkiye Diyanet Vakfi İslam Ansiklopedisi (İstanbul: TDV Yayınlar1, 1992), 5:321.

11 Fuat Sezgin, "Bedî‘ İlminin Tekamülü ve İstanbul Kütüphanelerinde Bulunan Bediiyyelere Ait Yazmalar Kataloğu” (Lisans Bitirme Tezi, İstanbul Üniversitesi, 1947), 28.

12 Şevki Dayf, el-Belaga Tatavvur ve Tarih (Kahire: Dâru'l-Meârif), 9.

13 Detaylı bilgi için bk. Ali Ebu Zeyd, el-Bedîiyyât fi 'l-Edebi'l-Arabî (Âlemü'Kütüb, 1402/1982); İzzet Marangozoğlu, "Arap Edebiyatında Bedî‘ ve Bedîiyyât” (Yüksek Lisans Tezi, Selçuk Üniversitesi, 2005)

14 Hulusi Kılıç "Bedîiyyat," Türkiye Diyanet Vakfi İslam Ansiklopedisi (İstanbul: TDV Yayınları, 1992), 5: 323. 
sayılabilmesi için bazı şartlar aranmıştır: konusunun Hz. Peygamber’i methetmek olması, her beyitinde en az bir bedî‘ sanatının bulunması, beyit sayısının en az 50 olması, basît bahriyle yazılmış olması, revîsinin kesralı mim harfi olması. ${ }^{15}$

Bedîiyye türünde ilk kasideyi nazmeden şairin Safiyyuddîn el-Hillî olduğu kabul edilmektedir. ${ }^{16}$ İslam edebiyatında Safiyyüddin el-Hilli'den sonra XX. yüzyıla kadar yaklaşı 100 bediiyye kaleme alınmıştır. Bu bediiyyelerin bir kısmında her beyitte bir sanat pratik olarak uygulanmakla birlikte ilaveten bu sanatların isimlerinin ifadesi de bulunabilir. Bedîiyyelerde söz sanatlarının yoğunlaşmasından ötürü çoğu zaman anlaşılabilmeleri için şerhlere ihtiyaç duyulmuştur. $\mathrm{Bu}$ şerhleri kimi zaman bedîiyyeyi nazmedenler kimi zaman da muhtelif edipler yazmıştır. ${ }^{17}$

Safiyyüddin el-Hillî’den önce bedîiyye türünde atılan ilk adımın Ali b. Osman Emînüddîn es-Süleymânî el-Erbîlî (ö. 670/1271) tarafindan olduğu kabul edilmektedir. el-Erbîlı’’nin kasidesi her beytinde bir bedî‘ sanatının geçtiği ilk manzume olmakla beraber otuz altı beyit içermesi, çağdaşı olan bazı kişileri methetmesi, revîsinin lâm harfi olması, hafîf bahriyle yazılmış olmasından dolay1 bedîiyye olarak kabul edilmemektedir. ${ }^{18}$ Bununla birlikte Fuat Sezgin, el-Erbîlî’nin kasidesini bedîiyye türünün ilk örneği olarak kabul etmektedir. Zira ona göre Safiyyüddîn el-Hillî, meşhur bedîiyyesini yazarken Erbîlî’nin kasidesinden ilham almıştır. ${ }^{19}$

Bedîiyye türünde gerek sanatsal gücü gerekse sonraki literatürü belirleme bakımından en zengin olan eserleri ve şairlerini şu şekilde zikretmek mümkündür ${ }^{20}$ :

I. Ebü'l-Mehâsin Takıyyüddîn Ebû Bekr b. Alî b. Abdillâh b. Hicce el-Hamevî (ö. 837/1434), Bedîiyyetü İbn Hicce el-Hamevî

II. Ümmü Abdilvehhâb Âişe bint Yûsuf b. Ahmed b. Nâsır el-Bâuniyye ed-Dımaşkıyye (ö. 922/1516), el-Fethu'l-mübîn fì medhi'l-Emîn.

III. Abdülganî b. İsmâîl b. Abdilganî b. İsmâîl en-Nâblusî (ö. 1143/1731), Nesemâtü'l-eshâr fì medhi'n-nebiyyi'l-muhtâr ve Mâlihu'l-Bedi fi medhi'ş-şafi.

IV.Sadrüddîn Alî Hân b. Nizâmiddîn Ahmed b. Muhammed Ma'sûm el-Hüseynî el-Medenî (ö. 1120/1708) Envâru'r-rebi'fi envâi'l-bedi'

15 Bulut, Bedî‘ İlmi, 36.

16 Ebu Zeyd, el-Bedîiyyât, 59.

17 Kılıç "Bedîiyyat," 323.

18 Bulut, Bedî‘ İlmi, 37.

19 Sezgin, "Bedî‘ İlminin Tekamülü”, 43.

20 Sezgin, "Bedî‘ İlminin Tekamülü”, 48. 
Fuat Sezgin, tez çalışmasında 17 bedîiyye şairi ve şiirleri hakkında bilgi vererek İstanbul'daki yazma nüshalarını tespit etmiştir. Bu eserleri şu şekilde sıralamak mümkündür:

1. Safiyyüddin el-Hilli, el-Kâfiyetü'l-bedî iyye fi 'l-medâ 'ihi'n-nebeviyye

2. İbn Câbir el-Endelüsî, el-Hulletü s-siyerâ

3. Ebû Ca 'fer el-Endelüsî, Trrâzü 'l-Hulle fì şsifâ 'i'l-gülle (şerh)

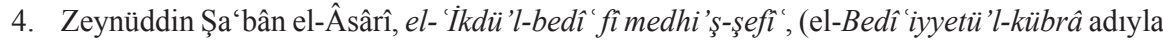
da bilinir) ve Bediu'l-Bedi'fi medhi'ş-șefi'

5. İbnü'l-Mukrî el-Yemenî, el-Cevâhirü' '-lâmi a fì tecnîsi 'l-ferâ idi' 'l-câmi 'a li'l-me 'âni'rrâ'i ${ }^{\prime} a$

6. Meçhul Müellif, Şerhu Nazîrati'l-Kasideti'l-bediiyye li-ibni' 'l-Mukri'

7. İbn Hicce el-Hamevî, Bedîyyetü İbn Hicce el-Hamevî

8. Celâleddin es-Süyûtî, Nazmü'l-bedî‘ fì medhi hayri şefì

9. Âiş̧e el-Bâûniyye, el-Fethu'l-mübîn fì medhi'l-Emîn. (ve aynı isimli şerhi)

10. Ebüssuûd Efendi, el-Bedîyyye

11. Zeynüddin el-Humeydî, Fethu'l-Bedi bi şerhi temlihi 'l-bedi fi medhi 'ş-şefi'

12. Mahmud el-Bosnavî, Lavaihu' 'l-bediyye bi-fethiyati' 'l-Ahmediyye fi hali nazmi rumuzi'lhumeydiye

13. Ebu'l-Vefa el-Urzî, Fethu'l-menihi' 'l-bedi'fi hâli 't-tirâzi 'l-bedi' fi imtidahi 'ş-şefi'

14. Ali Han b. Masum, Envâru'r-rebi'fi envâi'l-bedi'

15. Abdülganî en-Nablusî, Nesemâtü 'l-eshâr fì medhi'n-nebiyyi' 'l-muhtâr ve Mâlihu'l-Bedi fi medhi'ş-şafi

16. Ali Efendi b. Tacüddin el-Mekki, Miftahu'l-Ferac

17. Meçhul Müellif, el-Kasidetu'l-bediiyye

\section{Belâgat İlminin Tarihçesi}

Arapların câhiliye döneminde belâgatta ileri bir düzeyde olduğu bilinmektedir. Bunun en büyük göstergelerinden birinin de Hz. Muhammed'in mucizesinin Kur'ân olmasıyla ve davetçilerine yönelik en kesin delilinin Kur'ân'ın belâği açıdan meydan okuması olduğu kabul edilmektedir. ${ }^{21}$ Câhiliye dönemi edebiyatında bir meleke olarak varlığını gösteren Arap belâgati, Kur'ân'ın nüzûlüyle birlikte en mükemmel örneklerini ortaya koymuştur. Müdevven bir ilim olarak ise belâgatin doğuşu diğer dil bilimlerine nazaran daha geç bir dönemde gerçekleşmiştir. ${ }^{22}$ Hicrî III. asırda Câhiz, İbnü'l-Mu tez, Kudâme b. Ca` fer gibi ediplerin ortaya koyduğu

21 Dayf, el-Belaga, 9; Abdulkadir el-Hüseyin, el-Muhtasar fi'l-Belâga (Kahire: Dâru'l-Garîb, 2001), 22.

22 Ali Bulut, Belâgat : Meânî-Beyân-Bedî‘ (İstanbul: M.Ü. İlahiyat Fakültesi Vakfi Yayınları, 2015), 19. 
çalışmalar bu ilmi tesis etmekten ziyade meselelere teorik zeminde yaklaşan eserler olarak görülmüş, belâgatin sistematik bir ilim olarak Abdulkâhir el-Cürcânî’ (ö. 471/1078-79) ile başladığı kabul edilmiştir. ${ }^{23}$ Cürcânî Delâilu'l-i 'câz eseriyle meânî ilmini, Esrâru'l-belâga eseri ile de beyân ilmini geliştirmek suretiyle belâgat ilminin kurucusu olmuş, kendisinden sonra belâgat alanında telifte bulunanlar onun koyduğu kaidelere ve tasnifine sadık kalmışlardır.

Cürcânî sonrası belâgat çalışmaları onun ortaya koyduklarını ihtisar ve şerh etmek suretiyle devam etmiş, adeta Cürcânî ile belâgat ilmi gelişiminin son noktasına ulaşmıştır. ${ }^{24}$ Cürcânî’nin ortaya koyduğu belâgat birikimi Sekkâkî’nin tesiri ile yeni bir vecheye bürünmüştür. Sekkâkî Miftâhu'l-Ulûm'unun belâgat ilimlerini meânî, beyân, lafzî ve manevî muhassinât olarak ele aldığı üçüncü bölümünde belâgatı mantık esasları üzerinde yeniden tanımlayarak, kaideleri ve teorileri olan bir ilime dönüştürmüştür. ${ }^{25}$ Sekkâkî’nin kitabı belâgat ile ilgilenen alimlerin takriben beş asır boyunca ilgi odağı olmuş ve bu süreç Miftâh' 1 şerh ve ihtisarları üzerine yazılan kitaplarla geçmiştir. ${ }^{26} \mathrm{Bu}$ eserler arasında en çok şöhret bulan Hatib Kazvînî’nin, belâgatı meânî, beyân ve bedî‘ ilimlerinden müteşekkil olarak ele aldığı Telhîsu'l-Miftâh'ı olmuş; Telhîs üzerine çok sayıda şerh, manzume ve ihtisar kaleme alınmıştır. ${ }^{27}$ Sekkâkî’nin belâgat konularını felsefe ve mantık kaideleri doğrultusunda tanımlaması, edebî zevkin ihmal edildiği ve belâgatın kalıplarla sınırlandırıldığı eleştirisine maruz kalmıştır. ${ }^{28}$

Belâgat tarihinde Cürcânî öncesi döneme bakıldığında çeşitli ilim dallarında belâgat ilimlerinin kapsadığı konuların farklı saiklerle ele alındığı görülmektedir. Söz gelimi belâgat tarihi araştırmacısı Abdülkâdir Hüseyin belâgat ilmine katkıda bulunan ihtisas gruplarını i'câzu'l-Kur'ân eserleri kaleme alan âlimler, lügat ve nahiv âlimleri, edipler ve edebiyat eleştirmenleri şeklinde tasnif etmiştir. Buna göre Kur'ân-1 Kerîm' in i'cazını ortaya koyma saikiyle Vâs1l b. Atâ (ö. 131/748), Kisâî (ö. 189/805), Ferrâ (ö. 207/822), Ebû Ubeyde (ö. 209/824 [?]), Zeccâc (ö. 311/923), İbn Kuteybe (ö. 276/889) gibi alimler Meâni'l-Kur'ân, Mecâzu'l-Kur'ân, Nazmü'lKurân, Müteşâbihu'l-Kur'ân, I'câzü'l-Kur'ân benzeri isimlerle Kur'an'ın belâğ̣̂ özelliklerini i'câzını açıklama sadedinde telif ettikleri eserleriyle belâgata katkıda

23 Mehmet Akif Özdoğan, "Belâgatın Sistematize Edilmesinde es-Sekkâkî ve el-Kazvînî’nin Rolü," Dinbilimleri Akademik Araştırma Dergisi 4, no:2 (2002), 106.

24 Abülaziz Atîk, fi 'l-Belâgati'l-Arabiyye (Beyrut: Dâru'n-Nahdati'l-Arabiyye), 23.

25 Atîk, fi'l-Belâga, 25.

26 Atîk, fi'l-Belâga, 27-28.

27 Atîk, fi'l-Belâga, 28.

28 Özdoğan, "Belâgatın Sistematize Edilmesinde es-Sekkâkî ve el-Kazvînî’nin Rolü,” 106. 
bulunmuştur. ${ }^{29}$ Lügat ve nahiv âlimlerinden Sibeveyh (ö. 180/796) el-Kitâb'ında ${ }^{30}$ Müberrid (ö. 286/900) el-Kâmil, el-Muktadab, el-Belâga gibi eserlerinde ${ }^{31}$ İbn Cinnî (ö. 392/1002) el-Hasâis, el-Muhteseb, Sirru's-Sanâ'a gibi eserlerinde ${ }^{32}$ belâgatın konularına yer vermişlerdir. Ediplerden Câhiz' in (ö. 255/869), Kitâbü'l-Beyân ve 'ttebyîn'inde ${ }^{33}$ İbnü'l-Mu'tez'in (ö. 296/908) Kitâbü'l-Bedî ‘ve Kitâbu tabakâti 'şşuarâ's ${ }^{34}$ ile Ebû Hilâl el-Askerî'nin (ö. 400/1009'dan sonra) Cemheretü'l-emsâl, Kitâbu's-sinâateyn 'inde ${ }^{35}$, İbn Sinan el-Hafâcî'nin (ö. 466/1073) Sirru'l-Fesâha' da ${ }^{36}$, İbn Reşîk'in (ö. 456/1064) el-Umde fî-Mehâsini'ş-şi'r ve âdâbihi eserinde ${ }^{37}$ belağate dair konular ele alınmıştır. Edebîyat eleştirmenlerinden Kudâme b. Ca' fer'in (ö. $337 / 948$ [?]) Nakdü'ş-Şi'r'inde ${ }^{38}$ Âmidî'nin (ö. 371/981) Kitâbü'l-Muvâzene beyne't-Tấiyyeyn (el-Muvâzene beyne Ebî Temmâm ve'l-Buhtürî), el-Mü'telif ve'l-muhtelif, gibi eserlerinde ${ }^{39}$ Kādî el-Cürcânî (ö. 392/1001-1002) el-Vesâta beyne'l-Mütenebbî ve husûmih eserinde ${ }^{40}$ Hâtimî'nin (ö. 388/998) er-Risâletü'lHâtimiyye, er-Risâletü'l-mûdıha gibi eserlerinde belâgata dair konuları incelenmiştir.

Belâgat tarihini kronolojik olarak tasnif eden çalışmalarda ilmî gelişime göre dört evreden söz edilmiştir. Bu durumda birinci dönem Kur'ân'ın nüzûlünden Hicrî IV. sonuna kadar olan, belâgatın tefsir, edebî tenkit ve kelâmi konularla iç içe olarak ele alındığ 1 dönemdir. ${ }^{41}$ Belâgatın ikinci dönemi ise Hicrî IV. asrın sonundan VII. asrın sonlarına tekabül etmektedir. Bu dönemde Ebû Hilâl el-Askerî, İbn Reşîk, İbn Sinan el-Hafâcî'nin çalışmaları ile Cürcânî'nin Delâilü'l-i'câz ve Esrarü'l-Belâga eserleri ile belâgat müstakil bir ilim olarak teşekkül etmiş ve belâgat 1stılahları gelişim göstermiştir. Yine bu dönemde Cürcânî'nin mezkûr iki kitabında tesis ettiği esasları temel alarak Kur'ân'ı baştan sona belâğî açıdan

29 Hüseyin, el-Muhtasar, 23.

30 Bk. Hüseyin, el-Muhtasar, 53.

31 Bk. Hüseyin, el-Muhtasar, 59.

32 Hüseyin, el-Muhtasar, 68.

33 Hüseyin, el-Muhtasar, 81.

34 Hüseyin, el-Muhtasar, 92

35 Hüseyin, el-Muhtasar, 96.

36 Hüseyin, el-Muhtasar, 109.

37 Hüseyin, el-Muhtasar, 125.

38 Hüseyin, el-Muhtasar, 143.

39 Hüseyin, el-Muhtasar, 151.

40 Hüseyin, el-Muhtasar, 167

41 Kılıç, "Belâgat," 381; Kenan Demirayak, M. Sadi Çögenli, Arap Edebiyatında Kaynaklar (Erzurum: Atatürk Üniversitesi Fen-Edebiyat Fakültesi Yayını, 2000), 78. 
ele alan Zemahşerî'nin el-Keşşâf eseri kaleme alınmıştır. ${ }^{42}$ Söz konusu dönemin önemli gelişmelerinden biri de Fahreddîn er-Râzî’nin (ö 606/1209) Cürcânî’nin iki eserini ve Reşî̉üddîn Vatvât'ın (ö 573 /11 77) Farsça kaleme aldı̆̆ı Hadâiku 's-sihr eserindeki söz sanatlarını bir araya getirerek yazdığı Nihâyetü'l-îcâz fí dirâyeti'li'câz min Esrâri'l-belâga ve Delâili 'l-i'câz kitabının bu dönemde olmasıdır. Sekkâkî’nin Miftâh'1 ve İbn Ebi'l-İsba'nın bedî‘ ilmine dair önemli çalışmaları et-Tahrîrü 't-tahbîr fî̀ ilmi'l-Bedî ve 'Bedî' 'u'l-Kur'ân bu dönemin ürünleridir. ${ }^{43}$ Belâgat iminin gelişimi için bir duraksama evresi olarak kabul edilen üçüncü dönem ise hicrî VIII. asır ile XIII. asır arasına karşılık gelmektedir. Bu dönemde yapılan çalışmalar Kazvînî'nin, Sekkâkî'nin Miftah'ının üçüncü bölümünü temel alarak yazdığı Telhîsü 'l-Miftah'ı üzerine kaleme alınan çok sayıda şerh, haşiye ve taliklerden ibarettir. Öte yandan bu dönemde bedî‘ ilminin pratik düzlemde geliştiği alternatif bir literatür olarak bediiyyât türü ortaya çıkmıştır. ${ }^{44}$ Dördüncü dönem ise XIII. yüzyıl sonlarından itibaren olan evredir, modern dönemle birlikte pek çok alanda gerçekleştiği gibi belâgat ilmine de farklı yaklaşımlar gündeme gelmiştir. ${ }^{45}$ Belâgat tarihinde ele alacağımız Aristo etkisine dair tartışmalar belâgatın birinci dönemi hakkında olup edip ve edebiyat tenkitçilerinin ortaya koyduğu eserler bağlamında cereyan etmektedir.

\section{Belâgatın Doğuşunda Aristo Etkisi Tartışmaları}

Belâgatın Aristo felsefesinden etkilenerek geliştiği yönündeki tartışma Taha Hüseyin'in 1931'de Leiden'de toplanan Oryantalistler konferansında sunduğu "Le rapport entre la rhétorique arabe et la rhétorique grecque" başlıklı tebliğinde dile getirdiği iddialarla başlamıştır. ${ }^{46}$ Bu tebliğ Abdulhamid el- 'İbâdî tarafindan Arapçaya tercüme edilerek ${ }^{47}$ Kudâme b. Ca fer'e isnad edilen Nakdü'n-nesr adl1 eserin girişine eklenmiştir. Taha Hüseyin bu konuşmasında "Aristo felsefede Müslümanların ilk muallimi olduğu gibi belâgatta da ilk muallimi olmuştur" şeklinde özetlediği görüşlerini delillendirmiştir.

Taha Hüseyin'in söz konusu iddiası ile belâgat tarihi araştırmacıları, Aristo'nun eserlerinin Arap belâgatini etkilediğini kabul edenler, bu tesirin belirli bir oranda

42 K1lıç, "Belâgat," 382; Demirayak, Arap Edebiyatında Kaynaklar, 78.

43 K1lıç, "Belâgat," 382

44 Kilıç, "Belâgat," 382; Dayf, el-Belâga, 273.

45 Kilıç, "Belâgat," 383.

46 Sezgin, "Bedî‘ İlminin Tekamülü”, 19.

47 Taha Hüseyin, “el-Câhiz'den Abdulkahir Dönemine Kadar Arap Belâgatı,” (çev. M. Akif Özdoğan) KSÜ Illahiyat Fakültesi Dergisi 8, (2006), 131. (Çevirmenin dipnotu)

48 Taha Hüseyin, “el-Câhiz'den Abdulkahir Dönemine Kadar Arap Belâgat1,” 157. 
gerçekleştiğini kabul edenler ve bu tesiri tamamen reddedenler olmak üzere üç farklı gruba ayrılmışlardır. Aristo tesirinin Taha Hüseyin'in öne sürdüğü düzeyde olduğunu kabul edenler arasında Berkūkī (1876-1944) ve Emîn el-Hûlî’yi (18951966) zikretmek mümkündür. Yunan felsefesinin kısıtlı bir oranda Arap belâgatini etkilediği yönünde görüş beyan edenlere ise Ahmed Bedevî, Muhammed Zağlûl Selâm, İbrâhim Selâme, Seyyid Abdülfettâh Hicâb gibi araştımacılar örnek verilebilir. Bu görüşe göre Aristo'nun belâgata etkisi iddia edildiği gibi büyük çapta olmayıp Arapların tabiatına sirayet etmemiştir. Nitekim Arap belâgatının ana kaynağı Yunan felsefesi değil Kur'ân'ın belâğî mucizesi olmuştur. Arap belâgatında Yunan felsefesi etkisini reddeden araştırmacılara Fazl Hasan Abbâs örnek gösterilebilir. ${ }^{49}$

Belâgat tarihi hakkında hangi hususları tartışmaya açtığının net bir şekilde tespit edilebilmesi için Taha Hüseyin'in açıklamalarını ele almak yararlı olacaktır. Taha Hüseyin Hicrî III. asrın ortalarına kadar olan dönemde tam anlamıyla teşekkül etmiş bir belâgattan söz edilemeyeceğini, bu dönemde genel geçer kaidelerin tespit edilmesi ve bunların medrese eğitimine dahil edilmesi suretiyle belâgatın oluşmasına katkı sağlayacak çalışmaların yapıldığını kabul etmektedir. Ona göre bu aşamadaki belâgat çalışmalarında üç farklı etnik unsur temel oluşturmuştur: belâgatta baskın bir etkiye sahip olan Arap kökeni, üslup bakımından ön plana çıkan Fars kökeni ve lafız-mana ilişkisini merkeze alan Yunan kökeni. ${ }^{50}$ Hicrî III: asrın ortalarına gelindiğinde nahiv ilminin gelişim süreciyle kıyaslandığında geride kaldığı görünen belâgat ilmi üzerine çalışmak isteyenler için oldukça geniş ve bakir bir alan bulunuyordu. ${ }^{51}$ Taha Hüseyin bu döneme kadar olan süreçte Helenistik kültürün Arap edebiyatını Mutezile kelamcıları vasıtasıyla dolaylı bir şekilde etkilediğini mutlak surette kabul eder. Bu bağlamda Mutezile, belâgatın gerçek kurucusu olarak kabul edilebilir. ${ }^{52}$ Arap edebiyatı üzerinde Helenistik kültürün en yüksek orandaki etkisi İbnü'l-Mukaffâ,, Abdulhamîd b. Yahyâ, Ahmed b. Yusuf gibi yabancı uyruklu divan kâtipleri ile Ebû Temmâm gibi yabancı asıllı şâirlerin eliyle gerçekleşmiştir. ${ }^{53}$ Bununla beraber kâtip ve şairler Yunan düşüncesinden istifade ederken kendi kriterleri ile bir tasarrufta bulunmuşlardır. Söz gelimi Şair el-Buhturî Aristo'nun geliştirdiği mantık ilmine sertçe karşı çıkmıştır. ${ }^{54}$

49 Mustafa İbiş, "Tarihte Belâgat İlminin Karşılaştığ ${ }_{1}$ Harici Problemler," Social Sciences Studies Journal 35, no: 5, (2019), 2582-2583. Detaylı bilgi için bk.Fazl Hasan Abbas, el-Belâgatü'lMüfterâ Aleyhâ Beyne'l-Esâle ve't-Tebeiyye (Dârü'l-Furkân, 1420/1999).

50 Hüseyin, “el-Câhiz'den Abdulkahir Dönemine Kadar Arap Belâgat1," 137.

51 Hüseyin, “el-Câhiz'den Abdulkahir Dönemine Kadar Arap Belâgatı," 138.

52 Hüseyin, “el-Câhiz'den Abdulkahir Dönemine Kadar Arap Belâgat1," 138.

53 Hüseyin, "el-Câhiz'den Abdulkahir Dönemine Kadar Arap Belâgat1," 139.

54 Hüseyin, “el-Câhiz'den Abdulkahir Dönemine Kadar Arap Belâgat1," 140. 
Taha Hüseyin, hicrî III. yüzyılın ortalarında Aristo'nun İshâk b. Huneyn tarafından Kitâbü'l-Hatâbe adıyla Arapçaya tercüme edilen Rhetorica'sını belâgat ilmi üzerine yazılan ilk eser olarak kabul eder. Bu tercümenin Câhiz'in vefatından sonra hicrî. III. asrın ikinci yarısından sonra yapıldığını muhtemel kabul eden Taha Hüseyin o tarihlerde İbnü'l-Mu 'tez'in Kitâbu'l-bed $\imath^{\star}$ isimli eserini yazdığını belirtmiştir. Kitâbu'l-bedî́ 'yi inceleyemediğini ifade eden Taha Hüseyin, ondan yapılan nakil ve atıflardan çıkarımda bulunarak İbnü'l-Mu 'tez'in çalışmasının Aristo'nun tesiri ile yazıldığına işaret etmektedir. ${ }^{55}$ İbnü'l-Mu'tez' in çağdaşı Kudâme b. Ca fer'in Nakdü 'ş-şi'r'inde ve sonrakilerin eserlerinde Kitâbü'l-Hatâbe'nin üçüncü bölümü ile benzerlik tespit eden Taha Hüseyin, mecaz, teşbih, mukabele, fasl, lafżın özellikleri gibi konuların Aristo'nun görüşlerine yakın bir şekilde ele alındığını ifade etmiştir. ${ }^{56}$ Taha Hüseyin, Arap belâgatçilerinin, Aristo'nun konuları ele alırken kullandığı örnekleri kullanmaktan kaçındıklarını yalnızca bir yerde aynı örneğe yer verdiklerini belirtmiştir. Söz konusu örnekte Aristo, mecazın teşbihe dayandığını açıklama sadedinde şairin, Akhilleus'den "Aslan gibi öne atıldı" diye söz etmesinde teşbihin, "aslan öne atıldı" sözünde ise mecazın bulunduğunu söylemiştir. ${ }^{57}$ Taha Hüseyin bu örneğin bütün belâgat kitaplarında Akhilleus yerine Zeyd yazılarak kullanıldığını ifade etmiş̦tir. ${ }^{58}$

Mecaz konusunda Abdulkâhir el-Cürcani'nin Zeyd-aslan örneğini kullandığına değinen Fuat Sezgin bu örneğin daha önceki eserlerde; söz gelimi Ebu Hilal elAskerî ve İbn Reşîk el-Kayrevânî’nin eserlerinde yer almayışıyla, hicrî beşinci asırda Rhetorica'nın İslam kitâbiyâtında yeniden gündeme geldiği kanısını desteklemektedir. Sezgin'e göre Rhetorica belâgat anlamındaki beyân ilminin doğuşunda değil, gelişiminde Aristo etkisinden bahsedilebileceğini kabul etmektedir. Nitekim aynı dönemde kaleme alınan İbn Sînâ'nın Şîâ’sında Rhetorica'nın etkisi daha açık görülmektedir. ${ }^{59}$

Belâgat alimlerinin Kitabü'l-Hatabe'yi incelemeyi sürdürmekle beraber Yunan edebiyatına vakıf olamamaktan ötürü Aristo'nun verdiği örnekleri anlamakta problem yaşadıklarını, ancak kendi şiirlerinde karşılığını buldukları mevzulardan yararlandıklarını ifade eden Taha Hüseyin, hicrî III-IV. asırlarda yabancı bir ilmi kendi bünyesine adapte etmek noktasında belâgat kadar başarılı bir ilmin olmadığını

55 Hüseyin, “el-Câhiz’den Abdulkahir Dönemine Kadar Arap Belâgatı,” 141.

56 Hüseyin, “el-Câhiz'den Abdulkahir Dönemine Kadar Arap Belâgat1,” 142.

57 Aristoteles, Retorik, İngilizce'den çev. Mehmet H. Doğan (İstanbul:Yapı Kredi Yayınları, 1993), 173.

58 Hüseyin, “el-Câhiz'den Abdulkahir Dönemine Kadar Arap Belâgat1,” 142.

59 Sezgin, "Bedî‘ İlminin Tekamülü”, 27. 
bildirmiştir. ${ }^{60}$ Taha Hüseyin böylelikle; belâgatın süreç içerisinde Araplara ait bir ilim hüviyetine büründüğünü, dolayısıyla belâgat âlimlerinin Helenistik kültüre kendilerini borçlu hissetmediklerini ifade etmiş, bu kanaatini Ziyâeddin İbnü'l-Esîr' in (ö. 637/1239) el-Meselü 's-sâ 'ir'de yer verdiği şu açıklamaları ekleyerek desteklemiştir ${ }^{61}$ :

"Hitabetteki anlamların kuralları belirlenip sınırlandırılmıştır. Bu konuda ilk sözü söyleyen Yunan bilginleridir. Ancak bu kurallar genel(külli) olup özel (cüzi) değildir. Kuşkusuz bu ilim sahipleri(belagatçılar) bu özelliklerden yararlanmaz ve bunlara ihtiyaçları da yoktur. Çöldeki deve güden bedevi bu tür ifadeleri anlamaz ve aklına böyle bir şey gelmez. Bununla birlikte şiir ve nesri kendiliğinden, doğal (tabiî) olarak söyler. Çölde yaşayan bedevinin doğal ve fitri kabiliyeti vardır denilirse, zaten şiir ve hitabet de doğal ve fitrî kabiliyete göre icrâ edilir. Bunlardan sonra şehirlere yerleşip, çöl görmeyen şâirlerin durumunu sorarsan ve şehre yerleşenler Yunan bilginlerinin naklettiği ve bu bilginlerden öğrenenlerin anlattıkları bilgileri öğrenmişlerdir dersen, sana şu cevabı veririm: Böyle bir şey olmamıştır. Ebû Nuvâs, Muslim b.Velîd, Ebû Temmâm, el-Buhturî, Ebû’t-Tayyib el-Mutenebbî ve diğer şâirlerle, yine Abdulhamîd, İbnu'l- 'Amîd, es-Sâbiî ve diğer kâtipler Yunan bilgisinden etkilenmemişlerdir"62

Taha Hüseyin, Grek felsefesi kaidelerinin Arap edebiyatında tatbik edilmesinin Kudâme b. Ca 'fer'in Nakdü'ş-şi'r eseri ile başladığına kâil olmuş ve bu kanaatini, kitabın alışılmışın dışında bir tarzda ele alınmş olması ve kavramların tanımlarında, kitabın konularının tasnif biçiminde ve içeriğinde Kitabu'l-Hatabe ile benzer noktaları tespit etmek suretiyle ispatlamaya çalışmıştır. Buna göre Kudâme'den sonra gelen Arap belâgatçileri Kudâme'nin metoduna uymaktan geri kalmamış ve Ebû Hilâl el-Askerî gibi âlimler onun tespit ettiği bedî‘ sanatlarını artırmaya gayret etmişlerdir. ${ }^{63}$

Taha Hüseyin Arap belâgatındaki Aristo etkisini Kudâme'ye nispet etmekle beraber bu tesiri başka bir müellife ait olduğunu düşündüğü Nakdü'n-nesr eseri üzerinden örneklemektedir. Nakdü'n-nesr'in Aristo'nun Rhetorica (Kitâbü'lHatâbe) ve De Poetica (Kitâbü'ş-Şi 'r) eserleri yanında Analitikler (Analytica Priora: Kitâbü'l-Kiyâs, Analytica Posteriora: Kitâbü'l-Burhân) ve Topikler (Topica: Kitâbü Mevâzı ' i'l-cedel) eserlerinden yararlandığını bir vakıa olarak görmektedir. ${ }^{64}$ Bununla beraber Taha Hüseyin, Aristo'nun Kitâbü'l-Hatâbe ve Kitâbü'ş-Şi 'r eserlerinin en genel ifadeyle İslam düşüncesine etkisini İbn Rüşd, İbn Sînâ ve Abdulkahir Cürcânî’ nin (ö. 471/1078-79) çalışmaları üzerinden açılamıştır. ${ }^{65}$

60 Hüseyin, "el-Câhiz'den Abdulkahir Dönemine Kadar Arap Belâgat1," 142.

61 Hüseyin, "el-Câhiz'den Abdulkahir Dönemine Kadar Arap Belâgat1," 143.

62 İbnü'l-Esîr, el-Mes'elu 's-Sâ 'ir, Bûlâk, 186, Aktaran Hüseyin, “el-Câhiz'den Abdulkahir Dönemine Kadar Arap Belâgatı," 13.

63 Hüseyin, "el-Câhiz'den Abdulkahir Dönemine Kadar Arap Belâgat1," 145-147.

64 Hüseyin, "el-Câhiz'den Abdulkahir Dönemine Kadar Arap Belâgat,", 151.

65 Hüseyin, "el-Câhiz'den Abdulkahir Dönemine Kadar Arap Belâgat1," 151-157. 


\section{Kitâbu'l-Bedî'de Aristo Etkisi}

Çağının şairleri arasında değişik tür ve temalarda kaleme aldığı şiirleri ile öne çıkan Abbasî halifesi ${ }^{66}$ İbnü'l-Mu tez Kitâbü'l-Bed lै adlı eserini telif ederek muhdes şairlerin çokça kullandığı "bedî‘" olarak isimlendirilen söz sanatlarının ayetlerde, hadislerde, sahabe sözlerinde ve öncekilerin şiirlerinde zaten mevcut olduğunu, muhdes şairlerin bu sanatlarda öncekileri kat'î surette geçemeyeceğini ispatlamayı amaçlamıştır. ${ }^{67}$

İbnü'l-Mu 'tez'in Kitâbü'l-Bedî` eserini kaleme aldığında, kendisinden önce Câhiz ve İbn Kuteybe'nin çalışmalarında bedî‘ ilminin kapsamında sayılabilecek birkaç söz sanatı farklı isimlerle bilinmekteydi. ${ }^{68}$ Bununla beraber aradan kısa bir süre geçtikten sonra İbnü’l-Mu'tez'in bedî‘ sanatlarını sistemli bir ilim olarak ele alıp on yedi nev'i tespit etmesi, Fuat Sezgin'i Kitâbü'l-Bedî̀'de Aristo etkisi aramaya sevk etmiştir. ${ }^{69}$ Fuat Sezgin, Kitâbü̈l-Bedî́' ${ }^{\circ}$ de Aristo etkisinin varlığını farklı açılardan yaklaşarak tespit edilebileceğini öngörmüştür. İlk tespiti, Kitâbü'l-Bedî‘nin telifi ile Aristo'nun Rhetorica'sının Arapçaya tercüme edilmesi aynı senelere denk gelmesidir. Buna göre tarihte İshak b. Huneyn'in (ö. 298/910) Aristo'nun Rhetorica'sını tam olarak hangi senede Arapçaya tercüme ettiği bilinmemekle beraber, yaklaşık bir tarih aralığ 1 tahmin etmek imkan dahilindedir. İshak b. Huneyn'in ölmeden önce felce uğradığ 1 bilgisi göz önünde bulundurulduğunda tercümenin hicrî 298 senesinden birkaç yıl önce edildiği düşünülebilir. Nitekim bu eseri babası Huneyn b. İshak'ın (ö. 260/873) da tercüme etmesi mümkün olmakla beraber oğlunun tercüme ettiği bilinmektedir. ${ }^{70} \mathrm{Bu}$ durumda Huneyn $\mathrm{b}$. İshak'ın vefatından sonra, İshak b. Huneyn'in ömrünün son yıllarına tekabül eden bir tarihte (hicrî 260-298 arası) Rhetorica'nın tercüme edildiği söylenebilir. İbnu'l-Mutez'in ise eserinin ilk kısmını hicrî 274 'te yazmış olduğu bilinmekte, ikinci kısmını ise birkaç yıl sonra eklediği tahmin edilmektedir. ${ }^{71} \mathrm{Bu}$ durumda Rhetorica'nın tercüme edilmesi ile Kitâbü'l-Bedî‘ nin telif edilmesi aynı zaman dilimine denk gelebilmektedir. Ne var ki Fuat Sezgin, ilim ehlinden bir edip olan İbnü'l-Mu'tez'in Kitâbü'lHatâbe' den habersiz olmasını çok düşük bir ihtimal olarak değerlendirmiştir. ${ }^{72}$

66 Bkz. İsmail Durmuş, “İbnü’l-Mu'tez,” Türkiye Diyanet Vakfi İslam Ansiklopedisi (İstanbul, TDV Yayınları, 2000), 21: 143-144.

67 İbnü'l-Mu'tez, Kitâbü̈'l-Bedî‘ (Beyrut: Dâru'l-Mesîra, 1982), 1.

68 Sözgelimi el-mezhebü'l-kelâmî nev'iden Câhiz bahsetmiştir. (Bkz Dayf, el-Belâga, 70.)

69 Sezgin, Bedî‘ İlminin Tekamülü, 18-19.

70 Sezgin, Bedî‘ İlminin Tekamülü, 19-20.

71 Sezgin, Bedî‘ İlminin Tekamülü, 20.

72 Sezgin, "Bedî‘ İlminin Tekamülü”, 20. 
Fuat Sezgin Kitâbü'l-Bedî̀de Aristo etkisinin tespit edilebileceği bir diğer husus olarak eserin telif tarzını göstermektedir. Şöyle ki, İbnü’l-Mu'tez kitaba mukaddimeden sonra yazdığı birinci bölümünde istiâre, tibâk, tecnis/cinâs, reddu'lacuz ale's-sadr, el-mezhebü'l-kelâmî den oluşan beş adet bedî‘ nev'ini ayetler, hadisler ve şiirleler istişhatta bulunarak zikretmekte, nev'ileri tanımlamadan, doğrudan misaller üzerinden ele almaktadır. Bu bölümde bedî‘ nevilerini örneklendirirken önce ayet, hadis ve eski şairlerden sonra muhdes şairlerden alıntı yapan İbnü'l-Mu tez, sonrakilerin öncekileri asla geçemediğini kanıtlamaya çalışır. Zira o, Kitâbü'l-Bed̂̀`yi bu gayeyle yazdığnı ifade etmektedir. İbnü'lMu’tez kitabının birinci kısmında yer verdiği nev'ilerden yalnızca el-mezhebül kelâmî'nin Câhiz tarafından isimlendirildiğini bildirir. İbnül Mu’tez kitabının birinci bölümünün sonunda yani mezkur söz sanatlarını ele aldıktan sonra bedi' nevilerinin tamamlandığını ifade etmiş, kendisinden önce bedî‘ nev'ilerinin derlenmediğini ve kitabını hicrî 274 senesinde yazdığını bildirmiş, akabinde kendisinden kitabını Ebû Alî Yahyâ b. Ebî Mansûr el-Müneccim el-Fârisî'nin (ö. 215/830'dan sonra) istinsah ettiğini belirtmiştir. ${ }^{73} \mathrm{Bu}$ ifadelerinden sonra İbnü'l-Mu'tez, şiirin ve kelamın kimsenin tamamıyla kuşatamayacağı bazı güzelliklerini sayacağını ifade etmiş, bu suretle kitabının daha faydalı olmasını umduğunu aktarmıştır. Buna ilaveten İbnü'l-Mu 'tez söz güzelliklerine vakıf olmakla beraber bedî‘ sanatlarını beş unsur olarak derlediğini ancak ikinci bölüm olarak ekleyeceği sanatların da bedî‘ den addedilebileceğini bildirmiştir. ${ }^{74}$ Kitabın devamında ise on üç söz sanatı sıralayarak, tanımlamıştır. Fuat Sezgin ikinci bölümde zikredilen sanatların esasında on iki tane olduğunu kabul etmektedir. ${ }^{75}$

Fuat Sezgin'in Kitâbu 'l-Bedî‘nin telif tarzından yola çıkarak bedî‘ ilminin doğuşuna dair tespitte bulunduğu bir diğer husus da İbnü'l-Mu'tez'in, telif maksadını eserine yansıtma durumunda gözlenmektedir. Zira İbnü'l-Mu'tez kitabının maksadının muhdesûnun mütekaddimîni söz sanatlarında asla geçemediğini ispat etmek olduğunu ifade etmekle beraber eserin ikinci kısımında bu amacını unutmuş görünmektedir. Fuat Sezgin, Kitâbü'l-Bedî`nin ikinci bölümünde şiirle istişhadın azalmas1, ayet ve hadislere ise neredeyse rastlanılmamasından yola çıkarak kitabın ikinci bölümünün, eserin telif gayesine yönelik bir çalışma olmadığını ifade etmektedir. Zira müellif kitabın birinci bölümünde bedî‘ nevilerini sayfalarca yer tutan beyitlerle ve birçok ayet ve hadisle izah etmesine karşın ikinci bölümde istihada yoğunlaşmayıp nev'ilere tarif getirmeye odaklanmıştır. ${ }^{76}$

73 İbnü'l-Mu'tez, Kitâbü'l-Bedî'’, 58.

74 İbnü'l-Mu'tez, Kitâbü 'l-Bedî̀', 58.

75 Sezgin, "Bedî‘ İlminin Tekamülü”, 21-22.

76 Sezgin, "Bedî‘ İlminin Tekamülü”, 22-23. 
Mezkûr delillerden yola çıkarak Fuat Sezgin, Kitâbü'l-Bedî‘nin iki bölümün iki farklı tesirle kaleme alındığını iddia etmiştir. Buna göre kitabın beş bedî‘ sanatı içeren kısmı edebi tenkit gayesiyle hicrî 274 senesinde telif edilmiş, kalan kısmı ise aradan birkaç sene sonra yazılmıştır. İlk bölümde yer verdiği beş bedî‘ sanatı İbnü'l-Mu'tez'in kendi buluşları olmayıp daha öncesinde de bilinmekte olan sanatlardır. Nitekim şahit olarak getirilen örnekler bu sanatların daha önceden bilindiğini göstermektedir. İbn Ebi'l-İsba'nın bedi ismi altında değil farklı şekillerle eskiden beri bu nevilerin tanındığını söylemesi de bunu desteklemektedir. ${ }^{77}$ Kitâbü 'lBed̂̊ nin ikinci bölümünün yazılmasındaki sâik ise Fuat Sezgin'in tezine göre aynı tarihlerde Arapçaya tercüme edilen Rhetorica'nın etkisidir. Buna göre İbnü'l-Mu'tez eserinin birinci bölümünü yazıp bitirdikten sonra Kitâbü'l-Hatâbe ile karşılaşarak Aristo'nun zikrettiği nev' ilerin bir kısmını kitabının birinci bölümünde yer vermekle beraber diğer nev'ileri ise Arap dilinde kullanılmasını göz önünde bulundurarak karşılıklarını aradığı ve tespit ettiği kadarıyla kitabının ikinci bölümünü yazdığı yönünde bir tahminde bulunmaktadır. ${ }^{78}$

Fuat Sezgin, İbnü'l-Mu' tez'in Kitâbü'l-Bedî'si ile Aristo'nun Kitâbü'l-Hatâbe'sini karşılaştırarak tespit ettiği benzer noktaların, Kitâbü'l-Bed̂̊nin ikinci bölümünde Aristo etkisine delil teşkil ettiğini öne sürmektedir. Bu meyânda her iki eserde yer alan nev'i isimlerinden yola çıkarak bir karşılaştırmada bulunur. Sezgin, Rhetorica'nın Yunancadan ve Süryaniceden yapılan tercümelerinin kendisine ulaşamamasından dolayı nev'i başlıklarının orijinal isimlerinin zaman içerisinde değişme ihtimalinin bu mukayesede bir zorluk yarattığını ifade etmiş, bu nedenle tespitlerinin kesin

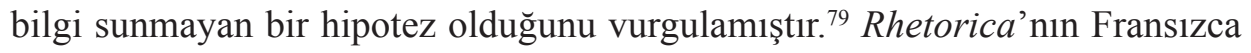
tercümeleri üzerinden Kitâbü' l-Bed $\hat{l}^{\prime}$ ile yaptı̆ğ karşılaştırma neticesinde Fuat Sezgin'in tespit ettiği müşterek bedî‘ nevileri şunlardır: Kitâbü'l-Bedî‘nin birinci bölümünde mutabakat, tecnîs ve istiâre, ikinci kısmında teşbih, mübalağa/ifrat, hüsnü'l-hurûc, el-hezlü'llezî yürâdü bihi'l-cid, hüsnü'l-ibtida ${ }^{80}$ Aristo'nun Théodecte isimli bir öğrencisine ithafen bedî‘ sanatları üzerine bir kitap yazdığını söylediğini ancak bu kitabın kayıp olduğunu bildiren Fuat Sezgin, Aristo'nun Rhetrorica'sının bir beyân veya bedî‘ kitabı olmayıp daha ziyade hatibin muvaffakiyeti ve dinleyici üzerinde müessir olabilmesi için nelere riayet etmesi gerektiğinden bahseden bir kitap olduğunu buna rağmen bedî‘ sanatlarından da dolaylı olarak söz etmesi nedeniyle İbnü'l-Mu'tez, Kudâme b. Ca'fer ve Abdulkâhir el-Cürcânî gibi belâgatçilerin istifade edebilecekleri tarafları haiz olduğunu ifade etmiştir. ${ }^{81}$

77 Sezgin, "Bedî‘ İlminin Tekamülü”, 23.

78 Sezgin, "Bedî‘ İlminin Tekamülü”, 23.

79 Sezgin, "Bedî‘ İlminin Tekamülü”, 25.

80 Sezgin, "Bedî‘ İlminin Tekamülü̈, 24-26.

81 Sezgin, "Bedî‘ İlminin Tekamülü”, 25-27. 
Zikrettiğimiz hususları göz önünde bulundurarak Fuat Sezgin İbnü'l-Mu`tez ile başlatılan bedî‘ ilminin farklı ve yeni bir muhtevayı içerdiğini ifade ederek bedî‘ ilminin tarihçesini İbnü'l-Mu tez öncesi iki asırlık dönemde bedi ilminin tekamül safhası ile İbnü'l- Mu'tez sonrası bedi ilminin genişleme safhası olmak üzere iki safhaya ayırmaktadır. ${ }^{82}$

Fuat Sezgin'in hocas1 Hellmut Ritter, İbnü'l-Mu tez'de doğrudan bir Aristo tesirini kabul etmiyor görünmektedir. 1953'de yayınlanan Esrârü'l-Belâga'nın edisyon kritik çalışmasına yazdığı mukaddimede İbnü'l-Mu'tez'in kitabında Yunan retoriğinden herhangi bir alıntı yapmadığını, Arapça kaynaklar üzerinden kitabını telif ettiğini belirmiştir. Ancak bununla beraber İbnü'l-Mu'tez' in kitabında yer verdiği mutabaka, i’tiraz, iltifat, rücû' gibi söz sanatlarının antik retorikte bulunduğunu ve bu durumun İbnü'l-Mu 'tez'i takip edenlerin eklediği bir çok bedî‘ sanatı için de geçerli olduğunu ifade etmiştir. ${ }^{83}$

Belâgat tarihi üzerine önemli araştırmalarda bulunan Şevki Dayf Taha Hüseyin'in makalesinde İbnü'l-Mu'tez'de Aristo etkisi bulunduğu yönündeki işaretini, onun Kitâbü'l-Bedî̀ yi görmemiş olmasına bağlamaktadır. Ona göre Kitâbu'l-Bedı̂‘nin içeriği Taha Hüseyin' in bu zannını geçersiz kılmaktadır. Bununla beraber Dayf'a göre İbnü'l-Mu'tez'in kitabının telif amacı belâgata Helenistik kültürden kaideleri dahil edenlere karşı çıkmak olduğunu belirterek iddiasını desteklemektedir. ${ }^{84}$ Şevki Dayf belâgatın tekamülünü birbiri ile mücadele halinde iki farklı grubun çatışması içerisinde yorumlamaktadır. Ona göre felsefecilere öykünen ve eserlerinde Aristo'nun hitabet ve şiir ile ilgili görüşlerini nakleden bir grubun karşısında,Yunan felsefesinden gelenleri şiddetle reddeden bir lügat ehli bulunmaktaydı. Şiirde yabancı unsurları reddeden dilciler arasında Sa'leb ve İbnü'l- Mu'tez'in çalışmalarını örnek göstermiştir. ${ }^{85}$ Bu durumda Dayf, İbnü'lMu'tez'de Aristo etkisinin varlığını reddetmekle kalmayıp, İbnü’l-Mu 'tez'i Aristocu belâgatçilerin karşı grubunda addediyor olmaktadır. Nitekim Arap belâgatında Aristo üzerine kapsamlı bir araştırma yapan Abbas Erhîle de İbnü’l-Mu 'tez'in gayretinin Arap belâgatinin otantikliğini ispatlamaya matuf olduğunu kabul etmektedir. ${ }^{86}$ Ülkemizde belâgat tarihi alanında önemli çalışmalarda bulunan akademisyenlerden Zafer Kızıklı, Şevki Dayf ile aynı kanaati paylaşmaktadır. Ona göre İbnü'l-Mu tez Kitâbü'l-Bedî ' de Arap belâgatında yabancı dil ve kültürlerden

82 Sezgin "Bedî‘ İlminin Tekamülü", 10.

83 Abdulkâhir el-Cürcânî, Esrarü'l-Belağa (Beyrut: Dâru'l-Mesîra, 1983), 4.

84 Dayf, el-Belâga, 70.

85 Dayf, el-Balâga, 66.

86 Abbas Erhîle, el-Eserü'l-Aristiyyu fi'n-Nakd ve'l-Belâgati'l-Arabiyyîn (Ribat, Menşûrâtü Külliyyeti'l-âdâb ve'l-ulûmi'l-insânîyye bi'r-Ribat, 1999), 317. 
alıntı olduğu yönündeki iddiayı çürütmeyi amaçlamaktadır. Zira “İbnü'l-Mu'tez'e göre, İslâm öncesi şiir ve Kur'ân'a dayalı Arapça söylem, retorik alanı başlı başına şekillendirmektedir." ${ }^{87}$

\section{Kudâme b. Ca'fer'in Nakdü'ş-Şi' r'deki İddiası}

Kitâbü'l-Harâc ve sinâ 'at(san 'at)i'l-kitâbe isimli eseriyle tanınan Kudâme b. $\mathrm{Ca}$ 'fer, Bağdat'ta divan kaipliği yapmış; fikıh, mantık, felsefe gibi alanlarda eğitim almış ancak çalışmalarına edebiyat, lügat ve belâgat alanında ağırlık vermiştir. Eserlerinde veciz ifadeler kullanması ve yalın anlatımıyla öne çıkmakla beraber ilmî kriterlere ve mantık tasniflerine önem verdiği için üslûbunun zafiyet taşıdığ 1 yönüyle eleştirilmiştir. ${ }^{88}$ Şiirin iyisini kötüsünden ayırmak üzere şiir tenkidi hakkında kitap yazan kimseye rastlamadığını ifade eden Kudâme ${ }^{89}$ üç bölüm olarak tasnif ettiği Nakdü 'ş-Şi 'r' in ilk bölümünde şiirin tarifi ve unsurlarını (lafız, mâna, vezin, kafiye) açıklayarak sonraki bölümlerde bu unsurların değerlendirmelerine yer vermektedir. Bununla beraber kitabında düzgün ve yerinde söz söyleme sanatının usul ve kaidelerini inceleyerek belâgat ilmine dahil olan çeşitli konuları ele almıştır. ${ }^{90}$

Fuat Sezgin'in bedî‘ ilminin tekâmülü hakkında problem olarak gördüğü hususlardan biri İbnü'l-Mu 'tez' in muasırı Kudâme b. Ca'fer' in Kitâbü' 'l-Bed̂̂̀' 'nin mevcudiyetinden habersiz görünerek söz sanatlarını nakdu'ş-şi'r adını verdiği ilim kapsamında ele alarak bu alanda yazılmış ilk eserin kendine ait olduğu iddiasıdır. ${ }^{91} \mathrm{Bu}$ problemin farkında olan belâgat tarihçileri çeşitli açıklamalar getirmişlerdir. Sözgelimi Şevki Dayf'ın açıklamasına göre, Kudâme b. Ca'fer kendisinden önce şiir tenkidi alanında yazan kimseyi bulamadığını söylemekle, kendisinden önce telifte bulunanların maksadı yerine getirmekte yeterli çalışmalar ortaya koyamadığını kast ediyor olmalıdır. Buna göre Kudâme, kendisinden önce bedî‘ sanatlara değinen ediplerden gerek Sa'leb'in (ö. 291/904) Kavâidü 'ş-Şi 'r' inde gerekse de İbnü'lMu'tez'in Kitâbü'l-Bedî̀'sinde övgüye değer bir ürün ortaya koyamadıklarını bunun sebebinin de Aristo'nun kitaplarındaki yol gösterici ışıktan mahrum kalmaları olduğunu düşünüyor olmalıdır. ${ }^{92}$

87 Kızıklı, “Arap Dilinde Retoriğin Bir Bilim Dalı Olarak Doğuşu, Gelişimi ve Öncüleri,” 1016.

88 Ömer Ferruh, Târîhu'l-Edebi'l-Arabî (Beyrut Dârü'l-İlmi li'l-Melâyîn, 1401/1981), 2: 434.

89 Kudâme b. Ca 'fer, Nakdü'ş-Şi'r, thk. Muhammed Abdülmun'im Hafâcî (Beyrut, Dârü'l-Kütübü'lİlmiyye), 61.

90 Cengiz Kallek, “Kud'ame b. Ca'fer,” Türkiye Diyanet Vakfi Íslam Ansiklopedisi (Ankara: TDV Yayınları, 2002), 26: 311.

91 Sezgin, "Bedî‘ İlminin Tekamülü”, 30.

92 Dayf, el-Belâga, 79. 
Fuat Sezgin, divan katipliği yapması hasebiyle saraya yakın olan ve İbnü'l-Mu'tez ile aynı hocalardan ders alan Kudâme'nin Kitâbü'l-Bedî‘'yi görüp yok saymasını imkan dahilinde görmez. Bu nedenle Kračkovskij 'nin Kudâme'nin Kitâbü'lBedî‘"yi bildiği ve bazı konularda isim vermeden alıntılar yaptığı yönündeki izahını da doğru bulmayan Fuat Sezgin, farklı bir kurguyla problemi çözmeye çalışır. Fuat Sezgin'e göre Kudâme, Kitâbü'l-Bedî̀'yi gerçekten de görmemiştir. Nitekim sonraki literatürde İbnü'l-Mu tez ve Kudâme'nin belirlediği bedî‘ nevilerinden ortak olanlara "tevârade aleyhi Kudâme me'a İbnü'l-Mu tez" ibaresi kullanılmış, “tevarüd” kelimesinin seçimiyle Kudâme'nin bedî‘ nevilerini İbnü’l-Mu tez'den almış olma ihtimalinden kaçınılmıştır. ${ }^{93}$

Nakdü 'ş-Şi'r, Kitâbü̈'l-Bedî̀ 'ye nisbetle teferruatlı ve dağınık bir tasnife sahiptir. Dolayısıyla Nakdu'ş-Şi'r'in Kudâme'ye aidiyeti tartışılmış, Makāmâti'l-Harîrî şarihi Mutarrizî (ö. 610/1213) gibi âlimler eseri, Kudâme'nin babası olan Cafer b. Kudame'ye nisbet etmişlerdir. Bu iddiayı kabul etmek durumunda, İbnü'lMu'tez'in Kitâbü 'ş-Şi'r'den faydalanması durumu gündeme gelir ki bu ihtimal tarihî veriler açısından problemlidir ve bu tespitte bulunmak pek kolay değildir. Bu sebeple Fuat Sezgin. Nakdü 'ş-Şi 'r 'in Kudâme'ye ait olduğunu kabul etmektedir. ${ }^{94}$

Fuat Sezgin, Kudâme'nin Kitâbü'l-Bedî̀ 'yi tanımamasından doğan tenakuza geliştirdiği özgün kurgu ile çözüm getirmeye çalışmaktadır. Buna göre Kudâme ile İbnü'l-Mu'tez arasındaki yaş farkı fazla olmayıp yaklaşık aynı dönemlerde yani Aristo'nun eserlerinin tercüme edildiği y1llarda telifte bulunmuşlardır. Kudâme'nin çeşitli eserlerinde Aristo'nun kitaplarını temel aldığı ve isimlerini Yunan müellifatından aldığı bilinmektedir. Bu durum Kudâme'nin Aristo'nun eserleriyle fazlaca ilgilendiğini göstermektedir. Aynı şekilde Nakdü 'ş-i'r' de müteaddid yerlerde Aristo'dan nakillerde bulunmuş olması onun Kitâbü 'l-Hatâbe'yi gördügünü ve ondan İbnü'l-Mu 'tez'in istifadesinden daha fazla yararlandığını ifade etmektedir. Zira Kudâme, Kitâbü'l-Hatâbe'de olup Kitâbü'l-Bedî "de olmayan pek çok bedî‘ nev'ine yer vermiştir. ${ }^{95}$

Fuat Sezgin Nakdü'ş-şiir' in Kitâbü'l-Bedî 'nin ilk bölümünün yazımından sonra, ikinci bölümün yazımıyla aynı senelerde yazılmış olduğunu kabul etmektedir. Buna göre Kitâbü'l-Bedî 'nin birinci bölümü hicrî 274 senesinde yazılmış ve herkesçe bilinmiştir. Birkaç sene sonra da Aristo'nın Rhetorica'si tercüme edilmiş̧ir. Kitâbü'l-Hatâbe tercüme edildiğinde ilgili araştırmacılar kitabı tetkike koyulmuştur. İbnü'l-Mu'tez Kitâbü'l-Hatâbe' de kendi kitabiyla benzer taraflar bulunca şahitler

93 Sezgin, "Bedî‘ İlminin Tekamülü”, 30-31.

94 Sezgin, "Bedî‘ İlminin Tekamülü”, 31.

95 Sezgin, "Bedî‘ İlminin Tekamülü”, 32. 
toplayarak bu benzerlikleri kitabına ikinci bölüm olarak eklemiştir. Bu esnada diğerleri gibi Kitâbü'l-Bedî̀'nin ilk kısmını tanıyan Kudame Rhetorica'yla karşılaşmıştır. Kudâme bu noktada ya Kitâbü'l-Bedî‘"nin birinci bölümüne benzer tarafları Kitâbü'l-Hatâbe'de bulup yeni ve müstakil bir eser meydana getirmeyi düşünmüş olmalı yahut da Kitâbü'l-Hatâbe'yi gördükten sonra Nakdü'ş-şi'r'i kaleme almış olmalıdır.

Böylelikle İbnü'l-Mu’ tez kitabının ikinci bölümüne birçok söz sanatı ekleyerek bedî‘ nev'ilerini daha önce kimsenin toplamadığına haklı olarak inanmıştır. Öte yandan da İbnü'l-Mu'tez'in eserinin son kısmından habersiz olarak Rhetorica'y1 görüp Nakdü'ş-şiir'i yazan Kudâme, kendisini bu alanda ilk eser telif eden kişi olduğuna kanaat getirmiştir. ${ }^{96}$

Fuat Sezgin'in Kudâme'ye nisbet ettiği belâgatla ilgili diğer bir kitap olan Nakdü'n-nesr'in Kudâme'ye aidiyeti tartışmalıdır. Fuat Sezgin, İbn Ebi'l-İ̀sba'nın Kudâme'ye ait iki Nakd'den bahsetmesi ve Safiyyüddîn el-Hillı̂'nin bedîiyyesini nazmederken yararlandığı kaynaklar arasında Nakdü'ş-şi'r ile Kitâbü'l-Harâc'1 saymasından hareketle eserin Kudâme'ye aidiyetini ispatlamaya çalışmıştır. ${ }^{97}$ Taha Hüseyin ise dikkatle incelendiğinde kitabın ona ait olmadığının ortaya çıkacağını ifade eder. Ona göre, kuvvetle muhtemel fikh ve din ilimlerinde yazdığı eserlerin işaret ettiği üzere kitap Şiî bir yazara aittir. Brockelman ise eserin, Kudâme'nin öğrencisi Ebû Abdullâh Muhammed b. Eyyûb'a ait olduğunu kabul etmektedir. ${ }^{98}$

\section{Beyân İlminin Başlangıcı}

Fuat Sezgin'in belâgat ilminin tarihi açısından problemli gördüğü bir diğer husus, başlangıçtan Hicrî III. asrın sonuna kadar olan dönemde belağatın doğuş ve gelişim evresine yöneliktir. Sezgin, belâgat ve içerdiği üç ilmin tek tek şahıslar ile başlatılmasına itiraz eder, ona göre beyân, meânî ve bedî‘nin birer ilim olarak ortaya çıkmaları, önceki dönemlere dayanır. Beyân ilmin tarihi Câhiz'in el-Beyân ve't-Tebyîn eseri ile başlatılmaktadır, ancak Fuat Sezgin bu dönemde beyân ile kastedilenin geniş manada belâgat olduğunu ve Câhiz'in çalışmasıyla beyân/ belâgat ilminin mütekamil şeklini aldığını kabul etmektedir. Zira beyân ilminin tekamülünün ilk aşamasında, müfessirlerin gayretleri, dilcilerin faaliyeti, yeni kültürlerle karşılaşma ve tercüme hareketlerinin etkisi bulunmaktadır. ${ }^{99} \mathrm{Bu}$ tesirlerin izahında Fuat Sezgin aşağıdaki açıklamalara yer vermektedir:

96 Sezgin, "Bedî‘ İlminin Tekamülü”, 34.

97 Sezgin, "Bedî‘ İlminin Tekamülü”, 34-35.

98 Hüseyin, “el-Câhiz'den Abdulkahir Dönemine Kadar Arap Belâgat1,” 148.

99 Sezgin, "Bedî‘ İlminin Tekamülü", 10. 
1. Tefsir ilmi ilk asırdan itibaren filolojik çalışmaları etkilemiştir. Belağtın bir çok meselesi Garîbu'l-Kur'ân, Meânî'l-Kur'ân, Mecâzü'l-Kur'ân gibi isimlendirilen eserlerle erken dönem tefsir çalışmalarında yer almıştır. ${ }^{100}$

2. Câhiliye döneminden beri Araplar için ayrıcalıklı bir yere sahip olan hutbelerin, dinleyicide etkili olabilmesi için îcaz, tenâfür, itnaptan kaçınma gibi ilkelere riayet edilmekteydi, hutbe üslubunda gerekli görülen bu özellikler belâgatın gelişmesine katkı sağlamıştır. ${ }^{101}$

3. Basra ve Kufe dil ekollerinin münazaralarında muhatapla konuşurken bilinmesi gereken bazı kurallara ihtiyaç ortaya çıkmış, bu ihiyaç belâgat alanının gelişiminde tesir göstermiştir. ${ }^{102}$

4. Hicrî II. asırdan sonra halifelere katiplik yapan ve divan tertip eden bir sınıf ortaya çıkmıştır. Bu katipler yazıda çok ileri gitmiş ancak konuşmada geri kalmışlardır. Söz konusu yazarların Arap diline daha önce görülmemiş kullanımlar sokması ve bu üsluplarının örnek teşkil etmesi, öğrenilmesi gerekli görülen bir takım yazı ve dil kurallarının ortaya konmasını sağlamıştır. Bunun sonucunda Yunan ve Hint-İran unsurları olmak üzere belağata yabancı unsurlar dahil edilmiştir. ${ }^{103}$

5. İslama giren gayri Arap unsurların kendilerini hakir görenlerden fikir sahasında intikam almak için geliştirdiği şuûbiyye hareketine karşı Arap dilinin ve belağatının üstünlüğünü ortaya koymak amacıyla bir hareket başlatılmıştır. Câhiz'in el-Beyân ve't-Tebyîn'i bu hareketin mahsulüdür. ${ }^{104}$

6. Emevî halifesi Halid b. Yezid döneminden itibaren başlayan tercüme harekelerinin umumi tesiri de eklenince hicrî III. asrın ortalarında hudutları geniş olan bu belağat/beyan oluşmuştur. ${ }^{105}$

Fuat Sezgin, İbnü'n- Nedim'in el-Fihrist' inde ve diğer kaynaklarda nakledilen, kırktan fazla Yunanca kitabın İsfahan'da uzun yıllardan beri bekleyip çürümeye yüz tutmuş bir halde bulunarak Bağdat'a nakledildiğine yönelik açıklama üzerinden yaptığı çıkarımlarla İran'da başka dillerden özellikle Yunanca'dan birçok eserin asıllarının ve tercümelerinin yaygın olduğu kanaatine varmaktadır. Bununla birlikte Sezgin, İbnü'n-Nedim'in tercüme eserlerden bahsederken belağatla ilgili çok sayıda eser nakletmesiyle de bu kanaatini desteklemiştir. ${ }^{106}$

Fuat Sezgin'e göre Câhiz'in el-Beyan ve't-Tebyîn'de biri İranlılara diğeri Hintlilere ait iki belâgat kitabından bahsetmesi, nakillerde bulunması, yine onun bu belâgatlara yönelik müstehzi ifadeleri onun döneminde belâgatın bilindiğini ve başka milletlerin belâgatlarının tanındığını göstermektedir. Dolayısıyla beyân ilminin bir kişi tarafından icat edildiğini kabul etmek doğru değildir. Nitekim beyân ilmi ile

100 Sezgin, "Bedî‘ İlminin Tekamülü”, 10.

101 Sezgin, "Bedî‘ İlminin Tekamülü”, 11.

102 Sezgin, "Bedî‘ İlminin Tekamülü”, 11.

103 Sezgin, "Bedî‘ İlminin Tekamülü”, 11-12.

104 Sezgin, "Bedî‘ İlminin Tekamülü”, 12.

105 Sezgin, "Bedî‘ İlminin Tekamülü”, 13.

106 Sezgin, “Bedî‘ İlminin Tekamülü”, 13. 
ilgili olarak İbn Haldûn bu ilmin Cafer b. Yahya el-Bermekî (ö. 187/803) tarafindan tesis edildiğini bildirmiş, bu bilgiyi desekleyen başka nakiller de olmuştur. İbn Nedim, Cafer b. Yahya'dan daha önce bu ilmi ele alan iki kişiden bahsetmektedir: Abdulhamid b. Yahya (ö.122) ve Cabir b. Hayyân et-Tûsî (ö.160). İbnü'n-Nedîm'in naklettiğine göre Abulhamid $b$. Yahya yalnızca belâgatın yollarını kolaylaştırmış, Ebû Hayyân ise birçok telifte bulunmuştur. Buna ilaveten Safiyyuddin el-Hillî bahsi geçen bedîiyyesini yazarken istifade ettiği kitapların arasında İbnü's-Sikkît'e (ö. 244/858) isnat edilen Kitâbu'l-Beyân adlı bir esere yer vermektedir. Fuat Sezgin mezkûr eserlerin muhtevasının bilinmese dahi bir kısmının beyan/belâgat ile ilgili olduğunu düşünmekte, dolayısıyla beyânın Câhiz'le başlatılmasının mümkün olmadığını bildirmektedir. ${ }^{107}$

Fuat Sezgin geniş anlamdaki belâgatı//beyânın mucidinin Câhiz olmadığını ifade etmekle beraber bu ilmin ilk aşamasında yabancı unsurlardan etkilendiğini kabul etmekedir. Sezgin, Câhiz'in el-Beyân'ından, sonraki dönemde Sekkâki ve Cürcâni ile olgunlaşan belâgat ilmine intikal eden içeriğin çok az olduğunu belirtmektedir. ${ }^{108}$ Bu ifadesi ile Fuat Sezgin'in yabancı tesiri altında bulunan belâgat birikimini erken döneme tahsis ettiği anlaşılmakta, bugünkü haliyle belâgat ilminde yabanc1 tesirinin olmadığına işaret ettiği anlaşılabilir.

Fuat Sezgin hicrî III. asrın sonlarına doğru belâgat/beyân için yeni bir safhanın başladığını öngörmektedir. Buna göre o döneme kadar belâgat kitapları haricindeki eserlerde bulunan ve sayısı beşi geçmeyen bedî‘ sanatları aniden çoğalmış; belağat beyân ve bedî‘ olmak üzere iki müstakil ilme ayrılmıştır. Nitekim İbnü’l-Mu`tez Kitabü 'l-Bedî‘ eseriyle yeni ve kendinden önce yazılan belağat kitaplarından tamamen farklı sistemde bir eser meydana getirmiştir. Öte yandan İbnü'l-Mu’tez'le aynı hocaların tedrisinden geçmekle beraber ondan çok sonraları vefat eden Kudâme b. Ca fer Nakdü'ş-Şi'r eserinde kendinden önce kimseye ait olmayan yeni bir şey bulduğunu iddia etmesi belâgat tarihi açısından yeni bir dönemin başladığını göstermektedir. ${ }^{109}$

\section{Sonuç}

Fuat Sezgin'in belâgat ilimlerinin doğuşu ve gelişimi çerçevesinde ele aldığ 1 meselelere yaklaşımları özgün açıklamalar içermektedir. Bununla beraber Sezgin'in değerlendirmelerinin literatürde yer almaması belâgat tarihi yazımı açısından bir eksikliktir. Yunan felsefesinin belirli bir oranda Arap belâgatini etkilediği yönünde

107 Sezgin, "Bedî‘ İlminin Tekamülü”, 14-17.

108 Sezgin, "Bedî‘ İlminin Tekamülü”, 17.

109 Sezgin, “Bedî‘ İlminin Tekamülü”, 18. 
görüşlerini serd eden Sezgin, belâgat tarihi açısından çözülmesi gereken birtakım problemlere işaret etmiş ve döneminin şartları çerçevesinde bir kısmına çözüm üretmeye gayret etmiştir. Onun, Câhiz dönemi belagatinin sınırlarını genişleterek, Câhiz'in sonraki dönem belagatçıları ile arasında bir sürekliliğin olmadığını vurgulaması, güncel kullanımı ile meânî ve beyân ilimlerinin otantikliğini korumaya matuf bir çaba olarak değerlendirilebilir. Nitekim Sezgin, belâgat ilminin doğuşunda değil, gelişiminde Aristo etkisinden bahsedilebileceği kanaatine varmıştır.

Fuat Sezgin, Taha Hüseyin'in işaret ettiği ancak inceleme imkanı bulamadığı Kitâbü'l-Bedî̀ 'yi inceleyerek İbnü'l-Mu 'tez' in çalışmasının safhaları ile bedî‘ ilminin gelişim safhaları arasında bir paralellik kurmuş ve kitabın ikinci bölümünün Aristo'nun tesiri doğrultusunda yazıldığını tespit etmiştir. Kitabın birinci bölümünde ele alınan konuların ise daha önceden bilinmekte olduğunu düşünmektedir. Modern dönemde İbnü'l-Mu 'tez üzerine çalışma yapan bazı Arap dili belâgatı tarihçileri İbnü'l-Mu 'tez'in Yunan tesirine karşı bir mücadele olarak Kitâbü' 'l-Bed̂̂̀' 'yi kaleme aldığını kabul etmektedir. İleriki çalışmalarda birbiriyle taban tabana zıt olan bu yaklaşımlar, Kitâbü'l-Bedî‘'nin içeriğinde çeşitli analizler yapmak ve Fuat Sezgin'in dikkat çektiği hususları tahkik etmek suretiyle değerlendirilmelidir. Belâgat tarihi yazımı açısından izaha muhtaç bir problem olan Kudâme b. Cafer'in iddiasına Fuat Sezgin özgün bir izah getirmiş ve tarihi veriler çerçevesinde meseleyi aydınlığa kavuşturmuştur.

Finansal Destek: Yazar bu çalışma için finansal destek almamıştır.

\section{Kaynakça/References}

Abbas, Fazl Hasan. el-Belâgatü'l-Müfterâ Aleyhâ Beyne'l-Esâle ve't-Tebeiyye. Dârü'l-Furkân, 1420/1999.

Aristoteles. Retorik. İngilizce'den çev. Mehmet H. Doğan, İstanbul:Yapı Kredi Yayınları, 1993.

Atîk, Abülaziz. fi'l-Belâgati'l-Arabiyye. Beyrut: Dâru'n-Nahdati'l-Arabiyye, 2.

Bulut, Ali. Bedî‘ İlmi. İstanbul: M.Ü. İlahiyat Fakültesi Yayınları, 2016.

Bulut, Ali. Belâgat : Meânî-Beyân-Bedî‘. İstanbul: M.Ü. İlahiyat Fakültesi Vakfı Yayınları, 2015.

Dayf, Şevki. el-Belâga Tatavvur ve Tarih. Kahire: Dâru'l-Meârif.

Demirayak, Kenan, M. Sadi Çögenli. Arap Edebiyatında Kaynaklar. Erzurum: Atatürk Üniversitesi Fen-Edebiyat Fakültesi Yayını, 2000.

Durmuş, İsmail. “İbnü'l-Mu`tez.” Türkiye Diyanet Vakfi İslam Ansiklopedisi İstanbul, TDV Yayınları, 2000, 21.

Ebu Zeyd, Ali. el-Bedîiyyât fi'l-Edebi'l-Arabî. Âlemü'Kütüb, 1402/1982.

el-Cürcânî, Abdulkâhir. Esrarü'l-Belağa. Beyrut: Dâru'l-Mesîra, 1983.

el-Kazvînî, Ebü'l-Meâlî Celâlüddîn el-Hatîb Muhammed b. Abdirrahmân. Telhîsü'l-Miftâh. thk. Abdurrahman el-Berkûkî. Dârü'l-Fikri'l-Arabî, 1932. 
Erhîle, Abbas. el-Eserü'l-Aristiyyu fi'n-Nakd ve'l-Belâgati 'l-Arabiyyîn. Ribat, Menşûrâtü Külliyyeti'lâdâb ve'l-ulûmi'l-insânîyye bi'r-Ribat, 1999.

es-Sekkâkî, Ebu Yakub Siracüddin Yusuf. Miftâhu'l-Ulûm. thk.Nuaym Zerzûr. Beyrut: Dârü'lKütübi'l-İlmiyye, 1407/1987.

Ferruh, Ömer. Târîhu'l-Edebi'l-Arabî. Beyrut Dârü'l-İlmi li'l-Melâyîn, 1401/1981.

Hacımüftüoğlu, Nasrullah. “Bedi.” Türkiye Diyanet Vakfi İslam Ansiklopedisi. İstanbul: TDV Yayınları, $1992,5$.

Hüseyin, Abdulkadir. el-Muhtasar fi 'l-Belâga. Kahire: Dâru'l-Garîb, 2001.

Hüseyin, Taha. “el-Câhiz'den Abdulkahir Dönemine Kadar Arap Belâgatı.” çev. M. Akif Özdoğan. KSÜ İlahiyat Fakültesi Dergisi 8, 2006, 131.

İbiş, Mustafa.“Tarihte Belâgat İlminin Karşılaştığı Harici Problemler.” Social Sciences Studies Journal. 35, no: 5, 2019.

İbnü'l-Mu`tez, Ebü'l-Abbâs Abdullāh b. Muhammed el-Mu'tezz. Kitâbü'l-Bedî‘. Beyrut: Dâru'lMesîra, 1982.

Kallek, Cengiz. “Kud'ame b. Ca'fer.” Türkiye Diyanet Vakfi İslam Ansiklopedisi. Ankara: TDV Yayınlar1, 2002, 26.

Kılıç, Hulusi. "Bedîiyyat.” Türkiye Diyanet Vakfi İslam Ansiklopedisi. İstanbul: TDV Yayınları, 1992, 5.

K1lıç, Hulûsi. "Belâgat.” Türkiye Diyanet Vakfi İslam Ansiklopedisi. İstanbul: TDV Yayınları, 1992, 5.

Kızıklı, Zafer.“Arap Dilinde Retoriğin Bir Bilim Dalı Olarak Doğuşu, Gelişimi ve Öncüleri.” ICANAS 38 Uluslararası Asya ve Kuzey Afrika Çalışmaları Kongresi. Ankara: 2007.

Kudâme b. Ca 'fer, Ebü'l-Ferec Kudâme b. Ca fer b. Kudâme b. Ziyâd el-Kâtib el-Bağdâdî. Nakdü'şŞi'r. thk. Muhammed Abdülmun'im Hafâcî. Beyrut, Dârü'l-Kütübü'l-İlmiyye.

Marangozoğlu, İzzet. “Arap Edebiyatında Bedî‘ ve Bedîiyyât”. Yüksek Lisans Tezi, Selçuk Üniversitesi, 2005.

Özdoğan, Mehmet Akif."Belâgatın Sistematize Edilmesinde es-Sekkâkî ve el-Kazvînî’nin Rolü.” Dinbilimleri Akademik Araştırma Dergisi 4. no:2, 2002.

Sezgin, Fuat. "Bedî‘ İlminin Tekamülü ve İstanbul Kütüphanelerinde Bulunan Bediiyyelere Ait Yazmalar Kataloğu”, Lisans Bitirme Tezi, İstanbul Üniversitesi, 1947. 
